\title{
Genes responsible for nisin synthesis, regulation and immunity form a regulon of two operons and are induced by nisin in Lactoccocus lactis N8
}

Institute of Biotechnology, Biocenter 1A, PO Box 56 (Viikinkaari 9), SF-00014 University of Helsinki, Finland

\author{
S. Runar Ra, Mingqiang Qiao, Tiina Immonen, Idoia Pujana \\ and Per E. J. Saris
}

Author for correspondence: S. Runar Ra. Tel: +358 04346042 . Fax: + 35804346028. e-mail: Ra@operoni.Helsinki.fi

\begin{abstract}
Nisin is a small post-translationally modified lanthionine-containing peptide (lantibiotic) produced by certain Lactococcus lactis strains which has a high antimicrobial activity against several pathogenic Gram-positive bacteria. Northern blots and RT/PCR analyses of the nisin-producing strain N8 revealed that the nisZBTCIPRKFEG gene cluster, responsible for nisin biosynthesis, immunity and regulation, consists of two operons, nisZBTCIPRK and nisFEG. The promoter of the nisFEG operon was mapped. The -35 to -1 region upstream of the transcription start of the nisFEG promoter showed $73 \%$ identity with the corresponding region upstream of the nisA and nisZ gene. In contrast to earlier reports, nisin was found to be secreted during the early stages of growth as well as later in the growth cycle. The secreted nisin was adsorbed on the surface of the cells and was released to the medium during mid-exponential growth, when the pH in the medium fell below 5.5. In nisZB antisense and nist deletion mutant strains constructed in this study the transcription of the nisin operons, nisin production and immunity were lost. Provision of external nisin restored the transcription of both operons in the mutant strains, showing that the operons are coordinately regulated by mature nisin. Nisin induction of the mutant strains also resulted in an increased amount of the Nisl protein and an increase in the level of immunity. Induction using higher concentrations of nisin yielded a higher level of immunity. These results showed that the nisin promoters are under positive control in an autoregulatory manner and that antimicrobial peptides can also function as signal molecules.
\end{abstract}

Keywords : nisin regulon, transcriptional regulation, signal transduction, Lactococcus lactis

\section{INTRODUCTION}

Nisin, subtilin and epidermin are peptide antibiotics called lantibiotics. These polycyclic peptides are post-translationally modified and contain the unusual amino acids dehydroalanine, lanthionine and $\beta$-methyllanthionine. They are produced by various $\mathrm{Gram}$-positive bacteria and are active against several Gram-positive spoilage bacteria and food pathogens such as Listeria, Clostridium and Bacillus species (Buchman et al., 1988; Banerjee \& Hansen,

Abbreviation: RT, reverse transcriptase.
1988; Schnell et al., 1988). The bactericidal effect of these peptides is based on depolarization of bacterial cytoplasmic membranes by pore formation (Gao et al., 1991). Nisin produced by Lactococcus lactis is the most important lantibiotic, and is widely used in the food industry (Delves-Broughton, 1990). Two naturally occurring nisin variants have been described, nisin $A$ and nisin $Z$, which differ in a single amino acid residue at position 27 (Buchman et al., 1988; Graeffe et al., 1991 ; Mulders et al., 1991). Recently the nis( $A / Z) B T C I P R K F E G$ gene cluster, comprising a $15 \mathrm{~kb}$ DNA fragment responsible for nisin production, regulation and immunity has been cloned and sequenced (Dodd et al., 1990; Steen et al., 
(a)

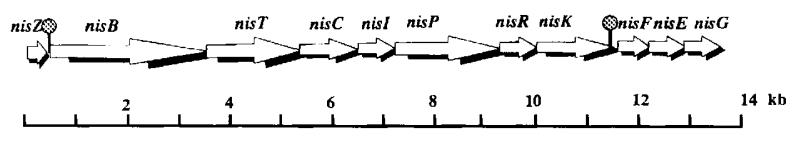

(b)
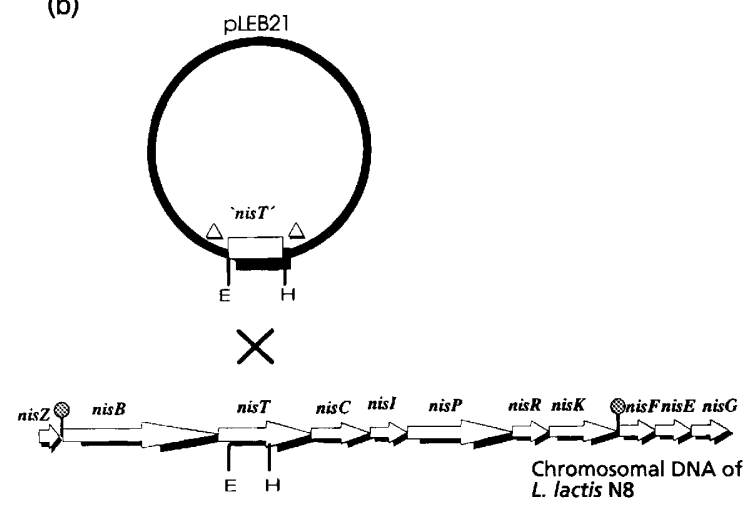

$\downarrow$ Crossing over

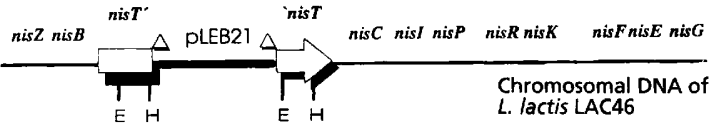

Fig. 1. (a) Genetic organization of the nisin operons of L. lactis. (b) Schematic representation of the construction of $L$. lactis LAC46 by plasmid integration. E, ECoRl; $\mathrm{H}$, HindlII.

1991 ; Engelke et al., 1992, 1994; Kuipers et al., 1993; van der Meer et al., 1993; Immonen et al., 1995; Siegers \& Entian, 1995).

$\mathrm{NisB}$ and NisC are believed to be necessary for chemical modification, which involves dehydration and lanthionine formation. Nis $T$ is an $A B C$ transport protein potentially responsible for the transport of prenisin across the cytoplasmic membrane. The lipoprotein NisI seems to play a role in nisin immunity (Kuipers et al., 1993; Engelke et al., 1994; Qiao et al., 1995), while NisP is a protease (van der Meer et al., 1993) which cleaves the leader of the modified nisin precursor peptide to active mature nisin. NisR and NisK are believed to form a twocomponent regulatory system necessary for nisin synthesis (Kuipers et al., 1993; Engelke et al., 1994; Immonen et al., 1995). The nisFEG genes encode a putative ABC transport system, which has recently been suggested also to be involved in nisin self-protection (Siegers \& Entian 1995).

Transcriptional studies have shown that the half-life of the structural nisin gene is $7-10 \mathrm{~min}$, and its promoter has been mapped (Buchman et al., 1988; Engelke et al., 1992;
Kuipers et al., 1993). Northern blot analyses with probes against nis $A$ and nis $B$ indicated two different monocistronic transcripts, a nis $A 0.3 \mathrm{~kb}$ transcript and a nis $B$ smear of $3 \mathrm{~kb}$ (Engelke et al., 1992). By using RT/PCR we have shown that a nis $Z B$ transcript exists ( $\mathrm{Ra} \&$ Saris, 1995) and that RNA processing results in the two observed transcripts. Based on DNA sequence data, five other potential promoters have been suggested in front of the nis $B, n i s T$, nis $C$, nis $R$ and nis $F$ genes, and two potential transcriptional terminators downstream of nis $B$ and nisK (Engelke et al., 1992; Dodd \& Gasson, 1994; Siegers \& Entian, 1995; Immonen et al., 1995). There have been conflicting reports about the expression of the nisin gene and the detection of nisin activity. Northern analysis against the structural nis $A$ gene with RNA isolated during all growth stages showed that the gene was expressed to about the same extent at all stages tested (Buchman $e t$ al., 1988; de Vuyst \& Vandamme, 1992). Whereas de Vuyst \& Vandamme (1992) observed a stringent correlation between nis $A$ expression and nisin activity, other workers have detected a delay of several hours between the onset of detectable nisin activity and the transcription of the structural gene (Hurst \& Peterson, 1971; Buchman et al., 1988). No transcriptional studies of the other genes of the nisin gene cluster have yet been described. Thus the transcriptional pattern of the nisin gene cluster and its regulatory factors has been poorly characterized.

In this paper we show that the nisZBTCIPRKFEG gene cluster is transcribed as two operons, nisZBTCIPRK and nisFEG, from two homologous promoters. We demonstrate that both operons are induced by external nisin and thus form one regulon. Our data show that mature nisin is produced at all growth stages, but is adsorbed onto the cell surface during early stages of growth, until the $\mathrm{pH}$ of the growth medium drops below $5 \cdot 5$.

\section{METHODS}

Bacterial strains and media. The nisin $\mathrm{Z}$ producing Lactococcus lactis subsp. lactis strain N8 (Graeffe et al., 1991), the nisin A producing strain ATCC 11454 (American Type Culture Collection) and the nisin-negative strain MG1614 (Gasson, 1983) were grown in M17 (Terzaghi \& Sandine, 1975) supplemented with $0.5 \%(\mathrm{w} / \mathrm{v})$ glucose and $0.5 \%$ sucrose instead of lactose (M17GS medium) at $30^{\circ} \mathrm{C}$ without shaking. The nisin-sensitive indicator strain Micrococcus luteus AL NCIMB 8166 (National Collection of Industrial and Marine Bacteria) and Escherichia coli DH5 $\alpha$ (Hanahan, 1983), the host for the plasmid vectors, were cultured at $37^{\circ} \mathrm{C}$ in $\mathrm{LB}$ broth, with shaking. Growth was measured as $\mathrm{OD}_{600}$, using a Shimadzu model UV-120-02 spectrophotometer.

Plasmid and mutant constructions. The superlinker from pSL1180 was cloned as an EcoRI-HindIII fragment into the Bluescript plasmid (Stratagene), yielding plasmid pLEB44. The multilinker was cloned from pLEB44 as a PstI fragment in the shuttle vector pVS68 (Valio, Helsinki, Finland), resulting in pLEB122. The lactococcal promoter P45 (Sibakov et al., 1991) was cloned from pKTH1799 as a ClaI-HindIII fragment in pLEB23 and from there as an BamHI-BglII fragment in pLEB122, yielding the expression vector pLEB124. The structural gene of nisin (nisZ) was cloned in pLEB124 as a BamHI fragment from pKTH1984 in sense and antisense 
Table 1. Probes for Northern analysis, primer combinations for RT/PCR and primers used for extension analysis

(a) DNA fragments used for generating probes for Northern analysis

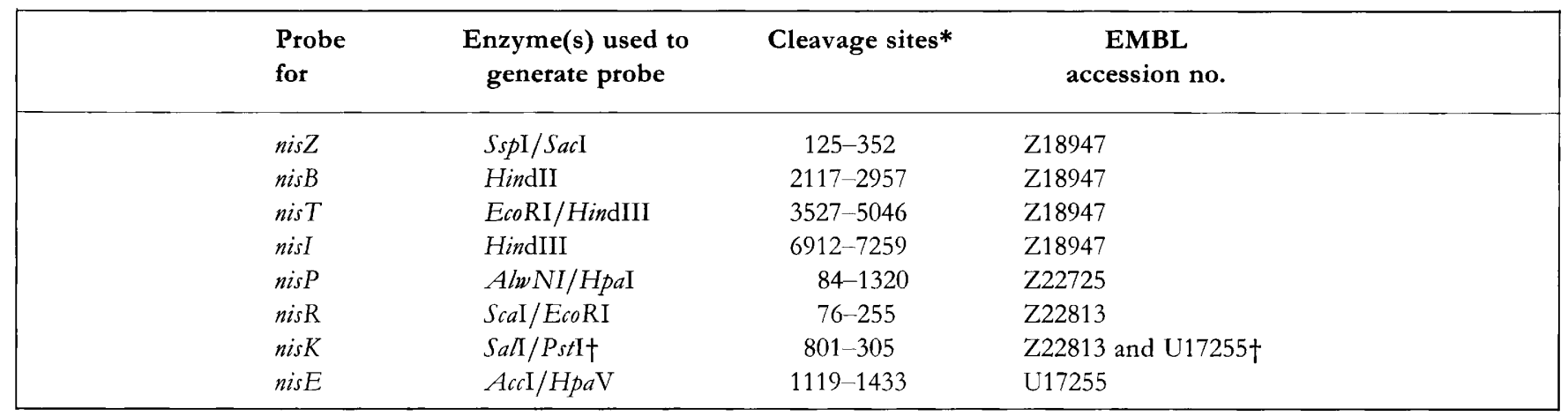

(b) Primer combination used for RT/PCR

\begin{tabular}{|lll|}
\hline RNA strech amplified & \multicolumn{1}{c|}{ Upstream primer } & \multicolumn{1}{c|}{ Downstream primer } \\
\hline- sis $^{\prime}$ ' & GTCTCCCTGAACCTAGCACAGAG & GAAATGCTTCTTTCAGAATGATAAC \\
$n i s^{\prime} T C I$ & AGTTTCTCACTTTTCATGTC & GAACTTTATTATTCAGAGC \\
$n$ s $^{\prime} I P '$ & TCTAAGAGATACCACTTCCTTAGC & GTATCCCGAGGTCTGAATGGGGGAG \\
$n$ s $^{\prime} P R K$ & TGCCATATCCGTCGACGC & AGGTCAGGATGATGCTAT'TAAC \\
\hline
\end{tabular}

(c) Primers used for extension analysis

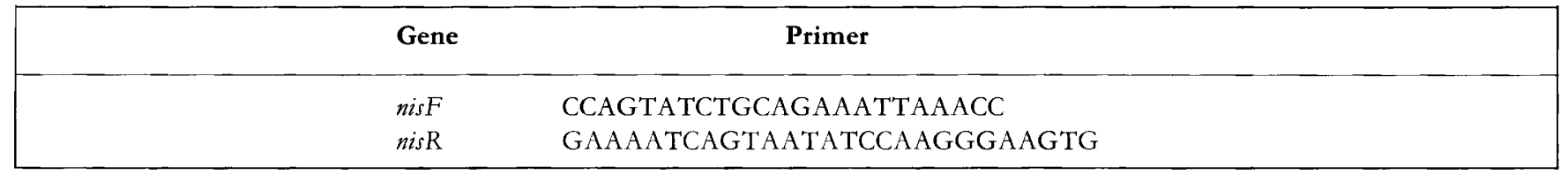

orientation, resulting in plasmids pLEB167 and pLEB168, respectively. These plasmids were electroporated into $L$. lactis ATCC 11454, yielding strains LAC15 and LAC16. Analysis of the plasmid content of the strains verified the presence of the electroporated plasmids. The nis $T$ mutation was made by integration of an E. coli plasmid having a Gram-positive selection marker (erm; Axelsson et al., 1988) and an internal EcoRI-HindIII fragment (1524 bp) of the nis $T$ gene of $L$. lactis N8 (Immonen et al., 1995) into the nisT gene of L. lactis N8 (Fig. 1). The correct integration was verified by Southern analysis and the transformant was named LAC46. The $3^{\prime}$ deletion of the nis T gene resulted in a gene capable of encoding a truncated NisT protein with a deletion of 86 amino acids from the C-terminus. All plasmids were isolated by the method of Carter \& Milton (1993). Otherwise established protocols were used (Maniatis et al., 1982).

RNA techniques and Northern hybridizations. RNA isolations and RT/PCR were done according to Ra \& Saris (1995). Thirty micrograms of RNA and $3 \mu \mathrm{g}$ RNA ladder (GIBCO BRL; cat. no. 15620-16) were fractionated on $0.6 \%$ agarose gels containing formaldehyde. After electrophoresis the gels were soaked in water for $20 \mathrm{~min}$ and then for $1 \mathrm{~h}$ in transfer buffer ( $8 \mathrm{mM} \mathrm{Na}_{2} \mathrm{HPO}_{4}, 17 \mathrm{mM} \mathrm{NaH} \mathrm{PO}_{4}$ ). RNA was transferred to Hybond N membrane with Bio-Rad's Trans-Blot cell overnight at $250 \mathrm{~mA}$ in a cold-room. After transfer, membranes were briefly rinsed in transfer buffer and then baked in a vacuum oven at $80^{\circ} \mathrm{C}$ for $2 \mathrm{~h}$. Membranes were prehybridized for $4 \mathrm{~h}$ at $57^{\circ} \mathrm{C}$ $(5 \times$ SSC, $5 \times$ Denhardt's solution, $0.5 \%$ SDS and $200 \mu \mathrm{g}$ denatured HS DNA ml-1). After addition of the probe, hybridization was performed in the same buffer overnight at $57^{\circ} \mathrm{C}$. Membranes were washed for 10 min with $2 \times \mathrm{SSC} / 0.1 \%$ SDS at $57{ }^{\circ} \mathrm{C}$, for $20 \mathrm{~min}$ with $1 \times \mathrm{SSC} / 0.1 \% \mathrm{SDS}$ at $57^{\circ} \mathrm{C}$, for 20 min with $0.5 \times \mathrm{SSC} / 0.1 \%$ SDS at $57^{\circ} \mathrm{C}$ and for $20 \mathrm{~min}$ with this solution at $65^{\circ} \mathrm{C}$, and finally with $0 \cdot 1 \times \mathrm{SSC} / 0 \cdot 1 \% \mathrm{SDS}$ at $65^{\circ} \mathrm{C}$. Washing of membranes for reprobing was done with $10 \mathrm{mM}$ TE $/ 0 \cdot 1 \%$ SDS $(\mathrm{pH} 8)$ at $90{ }^{\circ} \mathrm{C}$ for at least $2 \mathrm{~h}$. Membranes were monitored by exposing them to Kodak XOmat films to ensure that old probe had been fully removed before they were reprobed. Membranes were exposed to Kodak $\mathrm{X}$-Omat 100 films at $-70^{\circ} \mathrm{C}$ overnight before developing.

Labelling of probes. Labelling of $50 \mathrm{ng}$ of probe was performed with the Multiprime labelling system (Amersham) according to the manufacturer's instructions, in the presence of Amersham's $\left.{ }^{32} \mathrm{P}\right] \mathrm{dCTP}\left(3000 \mathrm{Ci} \mathrm{mmol}^{-1} ; 111 \mathrm{TBq}^{\mathrm{mmol}}{ }^{-1}\right)$. Free nucleotides were separated from the labelled DNA with Sephadex G50 Nick columns (Pharmacia). Table 1 shows the DNA fragments used for generating the probes.

Primer extension analysis. Primer extension experiments were done mainly according to Myöhänen \& Wahlfors (1993), with the following exceptions : $10 \mu \mathrm{g}$ or $20 \mu \mathrm{g}$ RNA with $10 \mathrm{pmol}$ of each primer was incubated for $5 \mathrm{~min}$ at $65^{\circ} \mathrm{C}$ in similar reverse transcription conditions as above. The tubes were transferred to $42{ }^{\circ} \mathrm{C}$ and $25 \mathrm{U}$ of $\mathrm{M}-\mathrm{MuLV}$ reverse transcriptase (RT) was added to the final reaction mixture $(20 \mu \mathrm{l})$. The dNTP mix contained normal dGTP instead of deaza-dGTP. After $45 \mathrm{~min}$ the volume was adjusted to $200 \mu \mathrm{l}$ and the reaction stopped with an equal volume of phenol/chloroform $(1: 1, \mathrm{v} / \mathrm{v})$. Following organic extraction and precipitation the pellets were dissolved

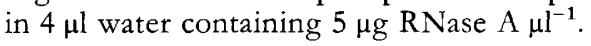


Nisin-immunity assay. The sensitivity of lactococcal cells to nisin was tested by adding $0-1000 \mathrm{IU}$ nisin $\mathrm{ml}^{-1}$ to overnight cultures diluted 1:50 in M17GS. Cultures were incubated overnight at $30^{\circ} \mathrm{C}$ and the growth was monitored by measuring $\mathrm{OD}_{600}$. Cells immune to nisin could grow in the presence of $1000 \mathrm{IU}$ nisin $\mathrm{ml}^{-1}$ whereas sensitive cells stopped growing in nisin concentrations above $5 \mathrm{IU} \mathrm{ml}^{-1}$. To determine the proportion of nisin-immune cells at a certain timepoint in fermentation experiments, the cells were washed in M17GS and incubated in M17GS containing nisin $\left(0-1000 \mathrm{IU} \mathrm{m}^{-1}\right)$ for $30 \mathrm{~min}$ at $30^{\circ} \mathrm{C}$ followed by determination of the viable count.

Nisin bioassay. Three samples from each chosen timepoint of the growth culture were taken. The $\mathrm{pH}$ of the first sample was adjusted to $4 \cdot 8$ with $\mathrm{HCl}$, to release nisin adsorbed onto the cells, followed by removal of the cells by centrifugation. The supernatant was heated at $56^{\circ} \mathrm{C}$ for $15 \mathrm{~min}$ to inactivate the remaining cells. From this sample (nisin from the growth medium and the cells) and dilutions thereof, $3 \mu \mathrm{l}$ was spotted on a plate of L-agar with $3 \mathrm{ml}$ soft L-agar containing $10^{5} \mathrm{M}$. luteus cells $\mathrm{ml}^{-1}$ on the surface (agar spot test). The second sample was directly centrifuged to separate the cells from the supernatant. The supernatant (nisin from the growth supernatant) was heat treated and used in the agar spot test as described above. The cells were resuspended in M17GS pH 4.8 to release nisin, and centrifuged. This supernatant (nisin from the cells) was also heat treated and applied to the surface of soft agar containing the indicator bacteria. The nisin bioassay plates with spots of the samples and dilutions of nisin (Sigma) were incubated at $37^{\circ} \mathrm{C}$ overnight. The diameter of the inhibition haloes in the uniform lawn of the indicator bacteria was measured. The values obtained and the minimal inhibitory concentrations of the samples were used to estimate the amount of nisin in the samples.

Nisin induction of lactococcal strains. Stationary-phase cells of LAC16 and LAC46 were incubated with $0 \cdot 1 \mathrm{IU}$ nisin $\mathrm{ml}^{-1}$ in $5 \mathrm{ml} \mathrm{M} 17 \mathrm{GS}$ medium at $30^{\circ} \mathrm{C}$ for $>10 \mathrm{~h}$. Cells used in the Western analysis were also induced in higher nisin concentrations (50 IU ml ${ }^{-1}$ ).

Protein purification and analysis. Immunodetection was done using the Protoblot kit (Promega) with a polyclonal rabbit antiserum recognizing the NisI protein. The NisI protein used for the immunization was isolated from E. coli cells producing a glutathionine- $S$-transferase-NisI protein fusion using a glutathionine-Sepharose column. The NisI protein was cleaved from the fusion protein with thrombin and purified by HPLCMonoQ.

\section{RESULTS}

\section{The transcriptional product of the nisZ promoter}

Northern analyses with nis $Z$, nis $B$, nis $T$, nis $I$, nis $P$, nis $R$ and $n i s K$ specific probes showed hybridization signals measuring from $0.24 \mathrm{~kb}$ to $11.0 \mathrm{~kb}$. Only the nis $Z$ probe gave a hybridization signal corresponding to the expected size of the gene; the other probes revealed smeared hybridization signals, similar to those that Engelke et al. (1992) obtained with a nis $B$ probe. The lack of detectable distinct bands was most likely due to the generally very short half-lives $(0 \cdot 5-2 \cdot 0 \mathrm{~min})$ of bacterial mRNAs (King \& Schlessinger, 1987), and the technical challenge of obtaining high-quality lactococcal RNA fast enough without any degradation. Because even a single attack

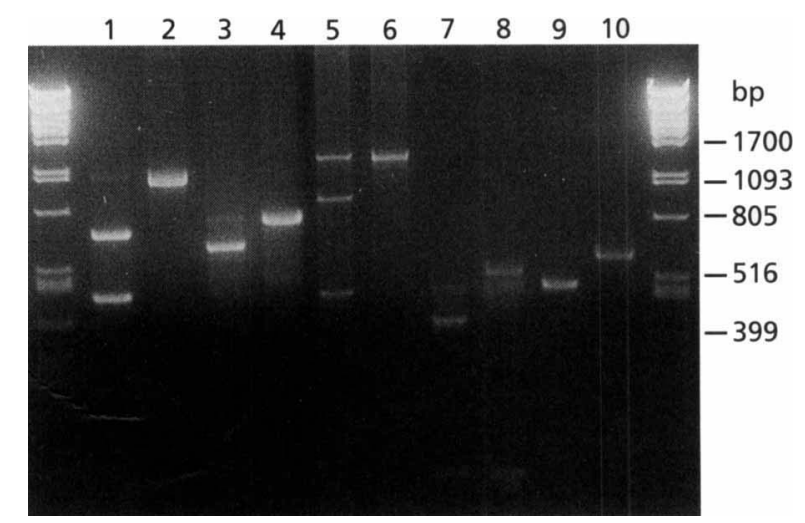

Fig. 2. RT/PCR analysis of the biosynthetic nisin operon. Lanes: $1, B c / l$ digest of the amplified nis'PRK' region (1115 bp); 2 , the nis'PRK' region; 3, a Hindlll digest of the amplified nis' $I P^{\prime}$ region $(758 \mathrm{bp}) ; 4$, the nis'/P' region; 5 , Styl digest of the amplified nis $^{\prime} T C l^{\prime}$ region (1504 bp); 6, the nis' $T C l^{\prime}$ region; 7 . Sphl digest of the nis'BT' region ( $569 \mathrm{bp}) ; 8$, the nis'BT' region; 9, Sacl digest of the amplified $n i s^{\prime} Z B^{\prime}$ region $(628 \mathrm{bp}) ; 10$, the $n^{\prime}{ }^{\prime} Z B^{\prime}$ region. The outer lanes contain size standards. The RT/PCR was done in more than triplicate experiments, with similar results each time. The sizes of the digestion products obtained correlated with the expected sizes.

anywhere on the $11 \mathrm{~kb}$ polycistronic transcript by an endonucleatic RNase alters the size of the hybridization signal, causing a smear, another approach was chosen. A series of $\mathrm{RT} / \mathrm{PCR}$ reactions was run with primers annealing to the $3^{\prime}$-end of a gene and to the $5^{\prime}$-end of the adjacent upstream gene, with the following concept: if the genes are expressed on the same RNA, the RNA stretch between these two genes will be amplified; if the genes are only expressed on different mRNA species, no amplification will be detected ( $\mathrm{Ra} \&$ Saris, 1995). To assure the true identity of the amplified RT/PCR products, they were cut with restriction enzymes to give DNA fragments of expected sizes (Fig. 2). All amplification results were positive, and combined with Northern analyses confirmed that one long nisZBTCIPR $K \mathrm{mRNA}$ was transcribed.

O. P. Kuipers (unpublished results in de Vos \& Simmons, 1994) has mapped a putative nis $R$ promoter. Despite efforts with several different primers and with RNA isolated from a nisin $Z$ producing strain, from a nisin $A$ producing strain at various growth stages, and from the mutant strain LAC46, we could not identify the same $5^{\prime}$ end mRNA (results not shown). Instead, one strong signal $31 \mathrm{nt}$ downstream of the identified transcriptional initiation site was always obtained. This site lies $10 \mathrm{nt}$ downstream of the ribosome-binding site of nis $\mathrm{R}$ and could represent a functional RNA inactivation cleavage site (King \& Schlessinger, 1987). Another very weak signal was also detected 20 nt upstream of the reported transcription initiation site, but no typical promoter sequences could be found in this region. When RNA from strain LAC16, which has no detectable nisZ promoter activity, was analysed with a nis $K$ probe, no hybridization signals could be detected. 
(a)

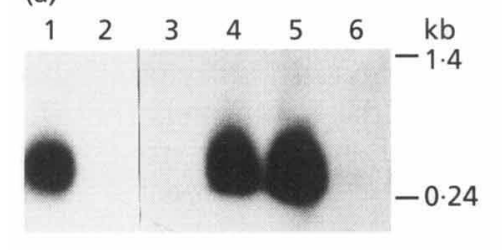

(b)

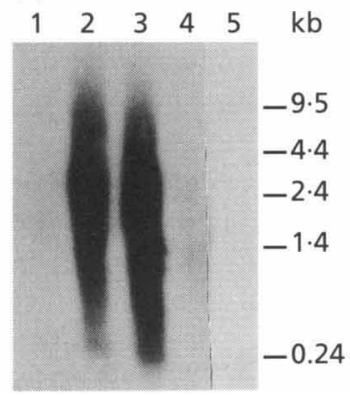

(c)

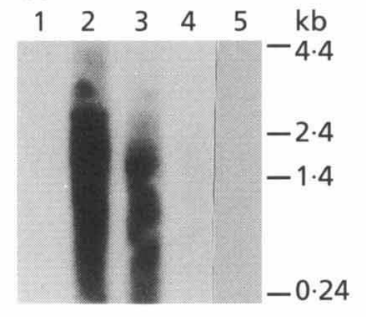

(d)

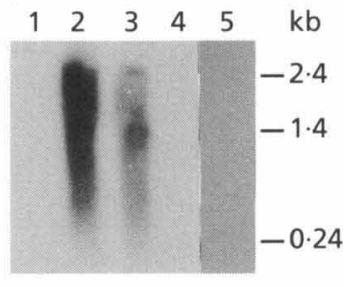

Fig. 3. Northern blot analysis of nisin-induced and noninduced lactococcal strains using a nisZ (a), nisB (b), nisK (c) and nisE (d) probe. (a) Lane 1, nisin-induced LAC46; lane 2, LAC46; lane 3, LAC16; lane 4, nisin-induced LAC16; lane 5, N8; lane 6, MG1614. (b-d) Lane 1, MG1614; lane 2, N8; lane 3, nisin-induced LAC16; lane 4, LAC16; lane 5, LAC46. The result in (a) was from one separate filter; the results in (b-d) were from another filter that was reprobed. In lane 5 in (c) and (d) the film was exposed for $1 \mathrm{~d}$ longer than the other lanes. In all panels RNA from the same isolations was used. The experiments were done in triplicate with freshly isolated RNA. Only minor variation in the results was obtained.

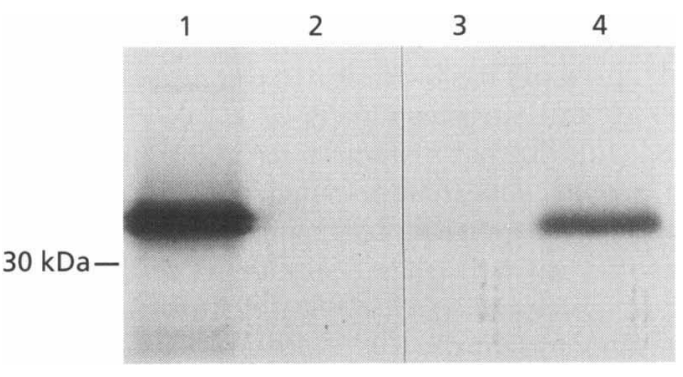

Fig. 4. Western blot analysis of nisin-induced and noninduced lactococcal strains using a Nisl-specific antibody. Lane 1, N8; lane 2, MG1614; lane 3, LAC46; lane 4, nisin-induced LAC46. The experiment was done in triplicate, giving similar results each time.

\section{The nisFEG operon and the mapping of its promoter}

Northern blot analysis of the nisin producer L. lactis N8 using a nisE specific probe revealed a band of $2 \cdot 3 \mathrm{~kb}$ (Fig. $3 \mathrm{~d})$. This size agrees with the expected size of a nisFEG transcript. Primer extension analysis revealed only one strong signal (results not shown), which mapped the transcriptional starting site to the $\mathrm{T}$ nucleotide $-27 \mathrm{bp}$ upstream of the ATG initiation codon of the nis $F$ gene. Upstream of the transcriptional start a characteristic Gram-positive -35 (CTGATT) and -10 (TGTTTTATA) region was identified. Compared to the nis A promoter (Kuipers et al., 1993) the -35 region differed by only one nucleotide, but the -10 region was noticeably different. However, if the proposed -10 region of the nis $A$ gene is moved $4 \mathrm{nt}$ upstream it would be separated by 1 nt from a preceding TG, which approximately half of the characterized lactococcal promoters possess (de Vos \& Simmons, 1994). In addition, with this adjustment the -35 and -10 region of the nis $\mathrm{F}$ and nis $A$ promoters show $80 \%$ identity. The total identity of the -1 to -35 region upstream of the transcription start of the nis $F$ and nis $A$ was $73 \%$.

\section{Inhibition of nisin production results in loss of transcription of the nisin operons}

Nisin production was inhibited by a plasmid insertion into nis T (LAC46) or by introducing pLEB168, con-

\section{Table 2. Nisin immunity of $L$. lactis strains}

Immunity (expressed as a percentage of wild-type immunity to $1000 \mathrm{IL}$ nisin $\mathrm{ml}^{-\mathbf{1}}$ ) was determined by the plate diffusion assay and from growth in liquid media containing varying amounts of nisin. ND, Not determined. The results presented are mean values from five experiments.

\begin{tabular}{|c|c|c|c|c|}
\hline \multirow[t]{3}{*}{ Strain } & \multirow[t]{3}{*}{ Description } & \multicolumn{3}{|c|}{ Immunity to nisin (\%) } \\
\hline & & \multirow{2}{*}{$\begin{array}{l}\text { No nisin } \\
\text { induction }\end{array}$} & \multicolumn{2}{|c|}{ Nisin induction } \\
\hline & & & $0 \cdot 01 \mathrm{IU} \mathrm{ml}^{-1}$ & $0 \cdot 1 \mathrm{IU} \mathrm{ml}^{-1}$ \\
\hline MG1614 & No nisin operons & $\geqslant 0.5$ & $\geqslant 0 \cdot 5$ & $\geqslant 0.5$ \\
\hline N8 & Nisin producer & 100 & $\mathrm{ND}$ & ND \\
\hline LAC15 & nis $Z B^{\prime}$ sense & $\geqslant 60$ & ND & ND \\
\hline $\mathrm{LAC16}$ & $n i s Z B^{\prime}$ antisense & 5 & 40 & 50 \\
\hline LAC46 & $n i s T$ mutant & $2 \cdot 5$ & $\geqslant 10$ & 20 \\
\hline
\end{tabular}



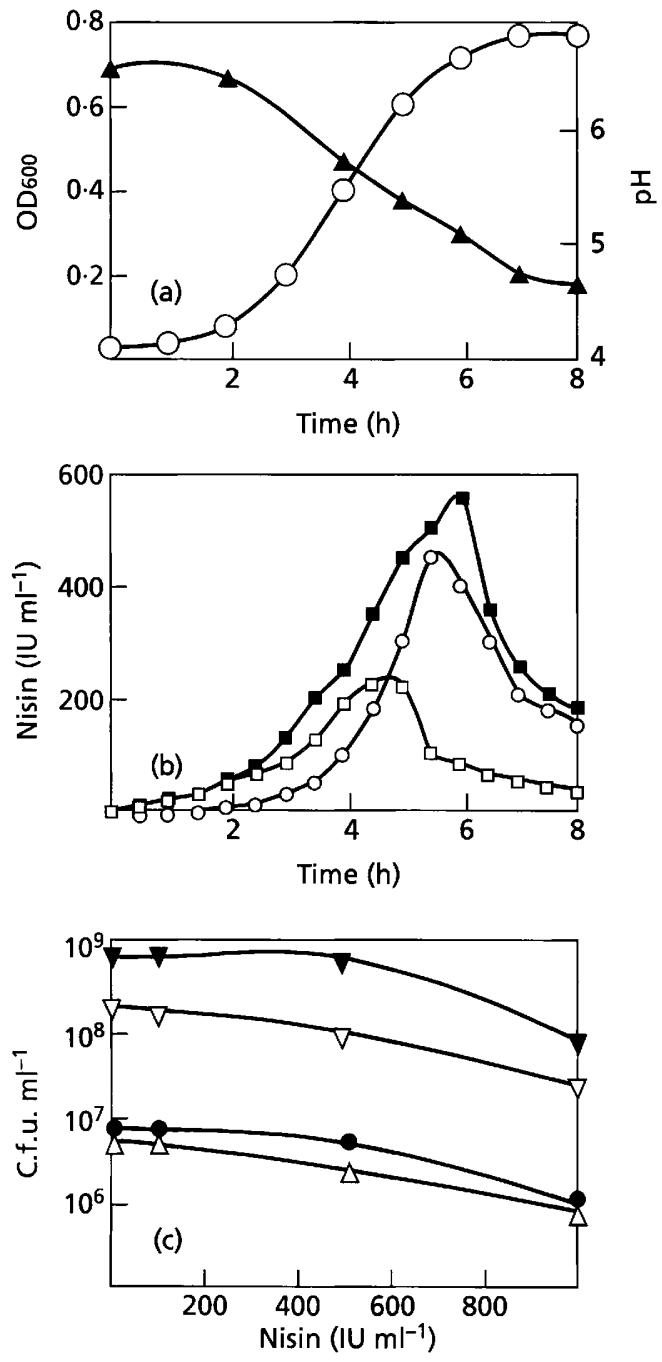

Fig. 5. Analysis of nisin production and immunity of the $L$. lactis strain N8. (a) Growth of the bacteria $\left(\mathrm{OD}_{600,} \Delta\right)$ and $\mathrm{pH}$ of the medium (O). (b) Amount of nisin produced during growth: $\square$, nisin from the surface of the cells; $O$, nisin from the growth supernatant; $\square$, nisin from the cells and the growth supernatant. (c) Proportion of nisin-immune cells at different stages of growth: $\triangle$, after $1 \mathrm{~h} ; 0$, after $3 \mathrm{~h} ; \nabla$, after $4.5 \mathrm{~h} ; \boldsymbol{\nabla}$, after $6 \mathrm{~h}$.

taining the pLEB124 expression vector with the nis $Z$ gene and the 10 first codons of the nis $B$ gene in the antisense orientation. In addition to the loss of nisin production the resistance to nisin dropped to less than $5 \%$ of wild-type immunity. Northern analysis of total RNA from strain LAC46 and the antisense-RNA mutant strain LAC16, using probes which hybridize to nis $Z$, nis $B$, nis $K$ and nis $E$ sequences showed that transcription of the two nisin operons was lost (Fig. 3). This showed that the two nisin promoters are strictly and coordinately regulated.

\section{Nisin induction of the nisin operons}

The loss of transcription from both nisin operons in strains LAC16 and LAC46 suggested that these operons are positively regulated by nisin or some of its precursor forms. Addition of nisin to the growth cultures of strain LAC16 resulted in an activation of the transcription of the nisin operons (Fig. 3). Nisin-induced transcription also resulted in an increased level of the NisI protein (Fig. 4). The level of nisin immunity of the mutant strains was increased by addition of nisin in amounts that do not inhibit even the most sensitive indicator strain. Higher nisin concentrations induced the cells to a higher level of nisin immunity (Table 2).

\section{Production of nisin}

Cells of the nisin Z producer $L$. lactis N8 were grown in batch culture using a complex medium. In order to avoid transfer of nisin from the previous fermentation, the cells used as inoculum were washed twice in M17 medium $\mathrm{pH} 4 \cdot 8$. Nisin production was followed by measuring nisin activity in samples taken every $30 \mathrm{~min}$ from the culture. Nisin activity associated with the growth supernatant and with the cells was measured by extracting nisin attached to the cell surface using growth medium with low $\mathrm{pH}$. Low $\mathrm{pH}$ has been shown to release nisin adsorbed in vitro to cell surfaces (Yang et al., 1992). The results showed (Fig. 5) that nisin activity could first be detected in the growth supernatant when the cells were entering the exponential growth phase, with a maximum at the late exponential growth phase, similar to results previously reported (Buchman et al., 1988; Engelke et al., 1994; de Vuyst \& Vandamme, 1992, 1993). The maximal nisin production rate $\left(3000 \mathrm{IU} \mathrm{ml}^{-1}\right.$ per $\mathrm{OD}_{600}$ unit $\left.\mathrm{h}^{-1}\right)$ was observed during the fifth hour at the end of the exponential growth phase. However, during the first $4 \mathrm{~h}$ of growth, when only minor nisin activity could be detected from the growth supernatant, the specific nisin production rate was remarkably high (2000-2500 $\mathrm{IU} \mathrm{m}^{-1}$ per $\mathrm{OD}_{600}$ unit $\mathrm{h}^{-1}$ ). Analysis of the nisin activity extracted from the cells showed (Fig. 5) that nisin produced during the first few hours of growth was adsorbed on the surface of the cells. When the $\mathrm{pH}$ of the growth supernatant fell below $\mathrm{pH} 5 \cdot 5$ the accumulation of nisin on the cell surfaces stopped and the cells started to release the adsorbed nisin, most likely due to the marked increase of nisin solubility below $\mathrm{pH} 5.5$ (Liu \& Hansen, 1990). At this stage of growth the amount of nisin in the supernatant started to increase significantly. The cells adsorbed only low amounts of nisin during the later stages of growth. The overall nisin production correlated with the sum of the nisin amount measured separately from the growth supernatant and the cells. The nisin immunity assay measured how many of the cells in a certain growth phase were immune to nisin and to what extent. The results showed (Fig. 5c) that the cells were approximately equally immune during all stages of growth.

\section{DISCUSSION}

\section{The transcripts of the nisZBTCIPRKFEG gene cluster}

Northern blot results combined with RT/PCR and recent results ( $\mathrm{Ra} \&$ Saris, 1995) showed that one long nisZBTCIPRK mRNA from the nis $Z$ promoter is trans- 
cribed. The nis $B$ gene and the six genes downstream of it were expressed at approximately the same level as the structural gene. Thus the inverted repeat between nis $A / Z$ and nis $B$ is not likely to function as a terminator as Steen et al. (1991) have suggested. The loop structure could function as a signal for the internal processing of the nisZBTCIPRK transcript at the intergenic gap between $n i s Z$ and nis $B$. The primer extension mapping of the nis $F$ promoter and the size of the transcript detected using a nis $E$ probe showed that nisFEG form one operon. Thus the putative transcription terminator downstream of nis $K$ is functional (Engelke $e t$ al., 1994; Immonen $e t$ al., 1995).

Previous results have suggested the existence of a nis $\mathrm{R}$ promoter (O. P. Kuipers, unpublished results in de Vos \& Simmons, 1994). However, we could not verify this putative nisR promoter by primer extension analysis. In addition, from RNA of the LAC16 and LAC46 strains, which have almost undetectable nis $Z$ promoter activity, no hybridization signals could be detected with a nis $K$ probe. Therefore, if the nis $R K$ genes are transcribed from another promoter than the nis $Z$ promoter, then the activity of this promoter is so low that it cannot be detected by Northern analysis. After nisin induction of strain LAC16 a strong nis $K$-specific signal was visualized in Northern analysis. The size of the signal was larger than the expected size of a nis $R K$ transcript. Thus the major part of the transcription of the $n i s R K$ genes seems to be regulated by the nis $A / Z$ promoter. These results showed that the nisZBTCIPRKFEG gene cluster consists of at least two operons, nisZBTCIPRK and nisFEG, resulting after RNA processing in three transcripts (nisZ, nisBTCIPRK and nisFEG).

\section{Regulation of the nisin operons}

Antisense-RNA inhibition of the structural nisin gene and inactivation of the nisT gene resulted in loss of transcription of both operons. Addition of nisin to the mutant cells incapable of nisin production restored the transcription of the nisZBTCIPRK and nisFEG operons. Nisin induction also increased the level of nisin immunity and that of the NisI protein. Using increasing amounts of nisin for induction resulted in increasing levels of immunity. These results showed that nisin biosynthesis and immunity are autoregulated by mature nisin from outside the cell. Cells in the stationary growth phase still had some adsorbed nisin on their surfaces. If such cells are transferred to fresh growth medium, the adsorbed nisin can immediately start a new cascade of amplification. This, in addition to the low amount of nisin needed for induction, could explain why the cells of the nisin producer were immune in the very early growth stages. If there is no nisin present due to peptidase activity, the initial inducer has to be synthesized from transcripts originating from uninduced nis $Z$ promoter activity. Northern blot analysis was not sensitive enough to detect this activity, but by Western analysis (Fig. 4, lane 4) the very low level of NisI produced by uninduced strain LAC16 was detected.

From the very early stages of growth to the stationary phase only minor variation in the level of nisin immunity and the specific nisin production rate was observed. This further indicated that the cells were already almost fully induced during the very early growth stages. Only if nisin production is disrupted, as in the mutant strains LAC16 and LAC46, does the autoregulatory circuit close and transcription of the nisin operons stop. In the stationary phase the nisin titre started to decrease even though the level of nisin immunity and transcription was still high. This could be a result of the release of non-specific proteolytic enzymes during cell lysis (de Vuyst \& Vandamme, 1992).

NisR (a response regulator) and NisK (a sensor histidine kinase), together forming a two-component regulator encoded by the first nisin operon, are needed for the expression of nisin (van der Meer et al., 1993; Engelke et al., 1994) and are likely to be involved in the signal transduction. The structure and function of many other two-component regulators are well characterized (Albright $e t$ al., 1989), but the inducing signal is unclear in most cases. We showed that active nisin can induce the transcription of its own gene and the genes downstream of it. Nisin also induced the transcription of the nisFEG operon involved in nisin immunity. This indicates that antimicrobial peptides have a more general role than just the antagonistic action. As shown in this study, nisin can also act as a signal for transcriptional activation, not only for its own structural gene but also for other genes and operons. An evolutionary reason for the autoregulation via signal transduction could be to increase immunity levels in response to high nisin production by neighbouring cells. The signal transducing system may also be used for communication between cells in order to achieve synchronized production of nisin, resulting in efficient killing of competing bacteria. The nisin promoters in combination with the NisR/NisK two-component regulatory pair are good candidates for the development of protein expression systems for use in food with an ideal regulation, because the inducer is generally regarded as safe and the nisin promoters can efficiently be turned on and off.

\section{REFERENCES}

Albright, L. M., Huala, E. \& Ausubel, F. M. (1989). Prokaryotic signal transduction mediated by sensor and regulator protein pairs. Annu Rev Genet 23, 311-336.

Axelsson, L. T., Ahrne, S. E. J., Andersson, M. C. \& Ståhl, S. R. (1988). Identification and cloning of a plasmid-encoded erythromycin resistance determinant from Lactobacillus reuteri. Plasmid 20 , 171-174.

Banerjee, S. \& Hansen, J. N. (1988). Structure and expression of a gene encoding the precursor of subtilin, a small protein antibiotic. $J$ Biol Chem 263, 9508-9514.

Buchman, G. W., Banerjee, S. \& Hansen, J. N. (1988). Structure, expression, and evolution of a gene encoding the precursor of nisin, a small protein antibiotic. $J$ Biol Chem 263, 16260-16266.

Carter, M. \& Milton, I. D. (1993). An inexpensive and simple method for DNA purifications on silica particles. Nucleic Acids Res 21, 1044. 
Delves-Broughton, J. (1990). Nisin and its application as a food preservative. J Society Dairy Technol 43, 73-76.

Dodd, H. M. \& Gasson, M. J. (1994). Bacteriocins of lactic acid bacteria. In Genetics and Biotechnology of Lactic Acid Bacteria, pp. 211251. Edited by M. J. Gasson \& W. M. de Vos. Glasgow: Blackie.

Dodd, H. M., Horn, N. \& Gasson, M. J. (1990). Analysis of the genetic determinant for production of the peptide antibiotic nisin. $J$ Gen Microbiol 136, 555-566.

Engelke, G., Gutowski-Eckel, Z., Hammelmann, M. \& Entian, K.-D. (1992). Biosynthesis of the lantibiotic nisin: genomic organisation and membrane localisation of the NisB protein. Appl Environ Microbiol 58, 3730-3743.

Engelke, G., Gutowski-Eckel, Z., Kiesau, P., Siegers, K. , Hammelmann, M. \& Entian, K.-D. (1994). Regulation of nisin biosynthesis and immunity in Lactococcus lactis 6F3. Appl Environ Microbiol 60, 814-825.

Gao, F., Abee, T. \& Konings, W. N. (1991). Mechanism of action of the peptide antibiotic nisin in liposomes and cytochrome $c$ oxidase containing proteoliposomes. Appl Environ Microbiol 57, 2164-2170.

Gasson, M. J. (1983). Plasmid complements of Streptococcus lactis $\mathrm{NCDO} 712$ and other lactic streptococci after protoplast induced curing. $J$ Bacteriol 154, 1-9.

Graeffe, T., Rintala, H., Paulin, L. \& Saris, P. (1991). A natural nisin variant. In Nisin and Novel Lantibiotics, pp. 260-268. Edited by G. Jung \& H.-G. Sahl. Leiden: ESCOM Science Publishers.

Hanahan, D. (1983). Studies on transformation of Eschericbia coli with plasmids. $J$ Mol Biol 16, 557-580.

Hurst, A. \& Peterson, G. M. (1971). Observations on the conversion of an inactive precursor protein to the antibiotic nisin. Can J Microbiol 17, 1379-1384.

Immonen, T., Ye, S., Ra, R., Qiao, M., Paulin, L. \& Saris, P. E. J. (1995). The codon usage of the nis $Z$ operon in Lactococcus lactis N8 suggests a non-lactococcal origin of the conjugative nisin-sucrose transposon. DNA Sequence 5, 203-218.

King, T. C. \& Schlessinger, D. (1987). Processing of RNA transcripts. In Eschericbia coli and Salmonella typhimurium: Cellular and Molecular Biology, pp. 703-718. Edited by F. C. Neidhart and others. Washington, DC: American Society for Microbiology.

Kuipers, O. P., Beerthuyzen, M. M., Siezen, R. J. \& de Vos, W. (1993). Characterization of the nisin gene cluster nis ABTCIPR of Lactococcus lactis. Requirement of expression of the nis $A$ and nisI genes for development of nisin immunity. Eur $J$ Biochem 216, 281-291.

Liu, W. \& Hansen, J. N. (1990). Some chemical and physical properties of nisin, a small-protein antibiotic produced by Lactococcus lactis. Appl Environ Microbiol 56, 2551-2558.

Maniatis,T., Fritsch, E. F. \& Sambrook, J. (1982). Molecular Cloning: a Laboratory Manual. Cold Spring Harbor, NY: Cold Spring Harbour Laboratory.

van der Meer, J. R., Polman, J., Beerthuyzen, M. M., Siezen, R. J., Kuipers, O. P. \& de Vos, W. (1993). Characterization of the
Lactococcus lactis nisin A operon genes nis $P$, encoding a subtilisinlike serine protease involved in precursor processing, and nis $\mathrm{R}$, encoding a regulatory protein involved in nisin biosynthesis. $J$ Bacteriol 174, 2152-2159.

Myöhănen, S. \& Wahlfors, J. (1993). Automated fluorescent primer extension. Biotechniques 14, 16-17.

Mulders, J. W. M., Boerrighter, I. J., Rollema, H. S., Siezen, R. J. \& de Vos, W. (1991). Identification and characterization of the lantibiotic nisin Z, a natural nisin variant. Eur $J$ Biochem 201, 581-584.

Qiao, M., Immonen, T., Koponen, O. \& Saris, P. E. J. (1995). The cellular location and effect on nisin immunity of the NisI protein from Lactococcus lactis $\mathrm{N} 8$ expressed in Escherichia coli and L. lactis. FEMS Microbiol Lett 131, 75-80.

Ra, S. R. \& Saris, P. E. J. (1995). Characterization of procaryotic mRNAs by R'T-PCR. Biotechniques 18, 792-795.

Schnell, N., Entian, K.-D., Schneider, U., Götz, F., Zahner, H., Kellner, R. \& Jung, G. (1988). Prepeptide sequence of epidermin, a ribosomally synthesized antibiotic with four sulfide-rings. Nature 333, $276-278$.

Sibakov, M., Koivula, T., von Wright, A. \& Palva, I. (1991). Secretion of TEM $\beta$-lactamase with signal sequences isolated from the chromosome of Lactococcus lactis subsp. lactis. Appl Environ Microbiol 57, 341-348.

Siegers, K. \& Entian, K.-D. (1995). Genes involved in immunity to the lantibiotic nisin produced by Lactococcus lactis 6F3. Appl Environ Microbiol 61, 1081-1089.

Steen, M. T., Chung, Y. J. \& Hansen, J. N. (1991). Characterization of the nisin gene as a part of a polycistronic operon in the chromosome of Lactococcus lactis ATCC 11454. Appl Environ Microbiol 57, 1181-1188.

Terzaghi, B. E. \& Sandine, W. E. (1975). Improved medium for lactic streptococci and their bacteriophages. Appl Microbiol 29, 807-813.

de Vos, W. M. \& Simmons, G. F. M. (1994). Gene cloning and expression systems in lactococci. In Genetics and Biotechnology of Lactic Acid Bacteria, pp. 52-97. Edited by M. J. Gasson \& W. M. de Vos. Glasgow: Blackie.

de Vuyst, L. \& Vandamme, E. J. (1992). Influence of the carbon source on nisin production in Lactococcus lactis subsp. lactis batch fermentations. J Gen Microbiol 138, 571-578

de Vuyst, L. \& Vandamme, E. J. (1993). Influence of the phosphorus and nitrogen source on nisin production in Lactococcus lactis subsp. lactis batch fermentations using a complex medium. Appl Microbiol Biotechnol 40, 17-22.

Yang, R., Johnson, M. C. \& Ray, B. (1992). A novel method to extract large amounts of bacteriocins from lactic acid bacteria. Appl Environ Microbiol 58, 3355-3359.

Received 31 July 1995; revised 1 December 1995; accepted 22 December 1995. 